\title{
Bożena Urbanek
}

Instytut Historii Nauki im. L. i A. Birkenmajerów PAN

ORCID 0000-0002-4526-6887

\section{Wileńska pediatria (19/9-1939)}

\section{Pediatrics in Vilnius (|9|9-|939)}

The article aims to show the development of pediatrics in Vilnius (Wilno) in the Borderlands of the Second Polish Republic in the interwar period. The text presents the beginnings of the organizational, scientific and staffing process, and it employs the sources from the Lithuanian Central State Archives (Lietuvos centrinis valstybès archyvas), as well as address lists and medical journals from the period.

Keywords: Vilnius, university, pediatrics

Słowa kluczowe: Wilno, uniwersytet, pediatria

Pediatria to - zdaniem prof. Wacława Jasińskiego', ojca wileńskiej pediatrii - najmłodsza gałąź nauk lekarskich. Ocenę tę, co prawda w znacznie szerszym kontekście, wypowiedział profesor w 1922 r. na pierwszym w wolnej Polsce zjeździe pediatrów². Zaznaczyć jednak trzeba, że pediatria rozwijana była na Wileńszczyźnie jeszcze przed wybuchem pierwszej wojny światowej. Jej podstawy tworzyli lekarze zatrudnieni w różnych placówkach, głównie w prywatnych gabinetach, ambulatoriach, lecz także instytucjach społecznych, a od drugiej połowy lat dziewięćdziesiątych XIX w. w niewielkim szpitalu dziecięcym, założonym „dla uczczenia cara Aleksandra III”. Szpital ten, już o profilu specjalistycznym, funkcjonował na wileńskim Zwierzyńcu przy zgromadzeniu rosyjskich sióstr miłosierdzia Czerwonego Krzyża³. W 1909 r. informowano też o zatrudnieniu lekarza chorób dziecięcych w szpitalu żydowskim przy ul. Zawalnej 42 - był nim dr Izydor Natanson. Ogólnie

1 Wacław Jasiński (1881-1936). W. Jasiński specjalizował się w pediatrii od 1905 r., pracował pod kierunkiem dr Józefa Brudzińskiego, ordynatora Szpitala Anny Marii w Łodzi. Więcej zob. M.M. Kamińska, Jasiński Wacław, [w:] Słownik biograficzny zasłużonych pediatrów, z. 1, red. E. Wilkoszewski, Warszawa 1985, s. 62; Przemówienie podczas uroczystego posiedzenia żałobnego w dniu 25 V 1936 r., ku uczczeniu pamięci Profesora Dra Wacława Jasińskiego. Dziekan Wydziału Lekarskiego Un .St. Batorego prof. dr Kornel Michejda, „Pamiętnik Wileński Towarzystwa Lekarskiego i Wydziału Lekarskiego Uniwersytetu Stefana Batorego" 1936, z. 3, s. 99.

2 Za: B. Kempińska-Mirosławska, Pediatria, [w:] Dzieje medycyny w Polsce. T. 2, lata 1914-1944, red. W. Noszczyk, J. Supady, Warszawa 2015, s. 395.

3 B. Urbanek, Kształtowanie się specjalności lekarskich na ziemiach polskich w latach 1860-1914, Warszawa 2010, s.89, 170-171. Lekarzem naczelnym w szpitalu w 1909 r. był dr Bolesław Żabko-Potopowicz, zob. Kalendarz ilustrowany „Kurjera Litewskiego" na rok 1909, Wilno 1909, s. 89. 
wileńskie środowisko lekarskie zajmujące się pediatrią w tymże okresie liczyło 19 specjalistów4 ${ }^{4}$ W późniejszym czasie część z nich współpracowała z wydawanym od 1908 r. w Warszawie „Przeglądem Pediatrycznym”, dzieląc się swymi doświadczeniami i rozwijając wiedzę o chorobach dzieci5.

\section{Stan lecznictwa pediatrycznego po $1919 \mathrm{r}$.}

Rozwój pediatrii i wzrost liczby specjalistów zajmujących się leczeniem dzieci nastąpiły po 1919 r. Na rozwój tej specjalności dodatkowo - a i może paradoksalnie - jak zauważyła Bogumiła Kempińska-Mirosławska, miała wpływ panująca wówczas sytuacja, konieczność podjęcia zmagań z wysoką śmiertelnością wśród dzieci, spowodowaną wojną, oraz chorobami, szerzącymi się w całych Kresach6. Były to głownie choroby zakaźne, w tym typowo dziecięce, jak odra, płonica i krztusiec, lecz także społeczne, np. gruźlica. Dlatego też dość wcześnie podjęto decyzję o uruchomieniu, na tym terenie uczelni kształcących lekarzy oraz o tworzeniu placówek medycznych. Już w 1919 r. starano się otworzyć w Wilnie uniwersytet $z$ wydziałem lekarskim. W planach nauczania przewidywano również uwzględnienie zajęć dydaktycznych i prowadzenie prac badawczych z zakresu pediatrii, a także poprawę stanu opieki i lecznictwa w tej dziedzinie. W 1919 r. miało też miejsce przejęcie przez magistrat Wilna społecznych zakładów leczniczych oraz dobroczynnych, $w$ tym tych o profilu dziecięcym ${ }^{8}$. Trzeba przypomnieć, że był to czas dla wilnian niezwykle trudny. Przez miasto przemieszczały się armie obcych wojsk, w tym rosyjskich i bolszewickich, niszcząc jego zabudowę, placówki lecznicze, utrudniając zaopatrzenie w żywność, środki higieny czy leki ${ }^{9}$. W takich okolicznościach przejęto pod zarząd miasta wspomniane struktury lecznicze i opiekuńcze. Należały do nich domy sierot, domy podrzutków, ochrony, żłobki, internaty, schroniska, czynna od 1909 r. przychodnia „Kropla Mleka"10 czy też wspomniany już szpital dla dzieci. Działały one pod patronatem różnych instytucji: społecznych, np. Towarzystwa Opieki nad Dziećmi, wyznaniowych, samorządowych, funkcjonowały zaś w systemie otwartej i zamkniętej opieki. Jak obliczono, trzy lata później w tzw. stałych ochronach przebywało 358 dzieci, w tym było 164 chłopców i 194 dziewczynek, w ochronach przewidzianych dla dochodzących dzieci - 188, w tym 83 chłopców i 105 dziewczynek ${ }^{11}$. Organizowano też ochrony izolacyjne: wspomina się np. istnienie

4 Ibid., s. 89-91.

5 B. Urbanek, Kształtowanie się specjalności lekarskich, s. 170-171. „Przegląd Pediatryczny” ukazywał się do wybuchu pierwszej wojny światowej.

6 B. Kempińska-Mirosławska, op. cit., s. 396. W latach 1919-1922 na ziemiach rodzącej się Polski powstawały trzy nowe pediatryczne ośrodki kliniczne: prócz Wilna w Warszawie i Poznaniu, zob. ibid.

7 B. Urbanek, Lekarze kresowi a dylematy praktyki medycznej w drugiej połowie lat 20. do 1933 r., (tzw. ustawy scaleniowej), [w:] Medycy polskiego pogranicza II Rzeczypospolitej 1918-1939, red. B. Urbanek, Warszawa 2018 , s. 48.

8 Lietuvos centrinis valstybejs archyvas w Wilnie [LCVA], sygn.64/24/65 (brak paginacji).

9 J. Kłos, Wilno, Przewodnik krajoznawczy, Wilno 1937, s. 35-41.

10 „Kropla Mleka” powstała z inicjatywy Józefa Montwiłł, prezesa Towarzystwa Opieki nad Dziećmi i Kuratorium Miejskiego nad Biednymi. W 1917 r. korzystało z pomocy tej instytucji 300 dzieci. Mieściła się ona w tzw. murach p-franciszkańskich przy ul Trockiej 14. Od 1914 r. instytucją tą kierował dr Ludwik Łukawski. Zob. Z Wilna - Z „Kropli Mleka”, „Dziennik Wileński” r. 2, 1917, nr 217, 22 IX 1917, s. 4.

11 LCVA, sygn. 64/19/3, k. 3. 
placówki o tym profilu przy ul. Kalwaryjskiej $1^{12}$. Instytucje te znajdowały się jednak rzadziej pod stałą, a częściej pod doraźną opieką lekarską.

\section{Lekarze}

Wedle danych z 1909 r. na 19 wileńskich lekarzy chorób dziecięcych 14 dodatkowo trudniło się diagnostyką i terapią chorób wewnętrznych, zapewne także osób dorosłych, a jeden z nich zajmować się miał również chorobami kobiecymi ${ }^{13}$. Jeszcze bowiem do początków lat trzydziestych XX w. lekarze zajmujący wyłącznie tą grupą chorób byli w mniejszości, uzupełniani (przynajmniej według spisu wykazów adresowych) przez lekarzy internistów, a w niewielkim stopniu - akuszerów i ginekologów. Przyjąć zatem można, że terapią dzieci do tego czasu zajmowali się też inni lekarze, a w zasadzie większość praktykujących w mieście lekarzy. Wywodzili się oni z różnych miast ziem zaborowych i ośrodków akademickich, np. Jasiński ukończył Cesarski Uniwersytet Warszawski ${ }^{14}$. Sytuacja ta zapewne utrzymywać się mogła do drugiej połowy lat dwudziestych, czyli do opuszczenia wileńskiej uczelni przez pierwszych absolwentów-lekarzy.

Tabela 1. Lekarze chorób dzieci w Wilnie w latach 1909-1939.

\begin{tabular}{|c|c|c|}
\hline Rok & Liczba ludności & Liczba pediatrów \\
\hline 1909 & 174291 & 19 \\
\hline 1925 & 128900 & 19 \\
\hline 1928 & 167454 & 22 \\
\hline 1935 & 208010 & 37 \\
\hline 1937 & 208305 & 28 \\
\hline 1939 & 208678 & 27 \\
\hline
\end{tabular}

Źródło: Kalendarz ilustrowany „Kurjera Litewskiego" na rok 1909, Wilno 1909, s. 81, 89-91; Księga adresowa m. Wilna. Wileński Kalendarz informacyjny na rok 1933, Wilno 1933, s. 43, 87-93; Księga adresowa m. Wilna 1935. Wileński Kalendarz informacyjny, Wilno 1935, s. 89-95; Wilno i woj. Wileńskie. Informator społeczno-gospodarczy i księga adresowa m. Wilna i woj. Wileńskiego, czerwiec 1937, Wilno 1937, s. 5, 38; Wilno i województwo wileńskie. Informator i Księga adresowa na rok 1939, red. P. Krasnopolski, Wilno 1939, s. 34.

W wykazach z poszczególnych lat figuruje też różne nazewnictwo dotyczące tej grupy specjalistów. Na ogół ich tytułem zawodowym, umieszczanym przy nazwisku, był „lekarz chorób dziecinnych" lub „dziecięcych”. Dopiero w 1927 r. po raz pierwszy obok nazwiska Wacława Szuniewicza, zatrudnionego w poradni „Kropla Mleka” na Małej Pohulance, pojawiło się określnie „pedjatra” ${ }^{15}$. Był to jednak wyjątek, którego nie znajduje się w innych wykazach, mimo - co warto zaznaczyć - pewnego popularnego charakteru tej publikacji, jaką niewątpliwie były kalendarze i wykazy adresowe z poszczególnych lat. W przytoczonym wykazie z 1927 r. odnajdujemy też inną specjalność: chirurgię dziecięcą, którą za- 
mieszczono co najmniej w spisie przy danych personalnych Józefy (?) Dowgiałło, zatrudnionej w wileńskiej Poradni Polskiego Zrzeszenia Lekarzy Specjalistów przy ul. Garbarskiej $3^{16}$. Jej nazwisko jednak nie figuruje w ogólnym wykazie lekarzy z tego roku, nie zostało też odnotowane $w$ rejestrze kalendarza $w$ roku następnym $(1928 \text { r. })^{17}$. Jej nazwisko - zresztą już jako dwuczłonowe - odnotowano rok później, w 1929 r., w wykazie adresowym, gdzie występuje jako dr Józefa Dowgiałło-Moszczyńska, zatrudniona, podobnie jak w 1927 r., w poradni Polskiego Zrzeszenia Lekarzy Specjalistów, lecz już tylko jako chirurg ${ }^{18}$. Zaobserwować zatem można od drugiej połowy lat dwudziestych XX w. pojawiające się wahania w stanie liczbowym specjalistów pediatrów. Wykazywano np. w 1927 r. spadek liczbowy osób zajmujących się leczeniem chorób dziecięcych sięgający aż 13 osób w porównaniu do poprzedniego ${ }^{19}$. Co ciekawe, zauważalny był za to przyrost tej grupy w następnych latach, aczkolwiek nie był stały i utrzymywał się do połowy lat trzydziestych. Jednakże zmniejszenie się liczby lekarzy-specjalistów chorób dzieci obserwowane po 1935 r. było tylko pozorne. Związane było - jak się wydaje - z rozdzieleniem i ścisłym już wydzieleniem poszczególnych specjalności, w tym przypadku chorób wewnętrznych czy chirurgii i chorób dzieci. Do tego czasu były one często w praktyce medycznej łączone. Występowanie tych tendencji można było jednak zaobserwować, jak pisano wyżej, zwłaszcza we wcześniejszym okresie.

Poprawie opieki medycznej, w tym stanu kadry medycznej w mieście i na północnowschodnich Kresach służyć miało, jak już wspomniano, powołanie na wileńskim Uniwersytecie Stefana Batorego wydziału lekarskiego.

\section{Katedra i Klinika Pediatryczna za czasów prof. Wacława Jasińskiego}

Utworzenie w ramach wydziału lekarskiego USB katedry i kliniki pediatrycznej z przygotowaną do tych celów kadrą nastąpiło w październiku 1922 r. ${ }^{20}$ Szefem katedry i kliniki został wspomniany dr Wacław Jasiński21.

Klinikę i katedrę uruchomiono przy ul. Sióstr Miłosierdzia 12, licząc jednak - ze względu na nienajlepsze warunki - że będzie to tymczasowa siedziba ${ }^{22}$. Do lat dwudziestych XX wieku dom ten służył jako mieszkanie sióstr zakonnych ${ }^{23}$. W części jego pomieszczeń zorganizowano salę wykładową, laboratorium, gabinety lekarskie ${ }^{24}$. W pozostałych po

16 Ibid., s.116.

17 Kalendarz wileński informacyjny 1928. Księga adresowa miasta Wilno, Wilno 1928.

18 Kalendarzy informacyjny 1929. Księga adresowa miasta Wilno, Wilno 1929, s.98, 107

19 Kalendarz wileński, informacyjny 1927, s. 109-112.

20 W. Jasiński, Sprawozdanie z Kliniki Chorób Dzieci Uniwersytetu Stefana Batorego w Wilnie w roku akademickim 1922/1923, „Pedjatrja Polska” 1923, nr 5, s. 325.

21 S. Trzebiński, Wydział Lekarski Uniwersytetu Stefana Batorego w latach 1919-1929, [w:] Księga pamiątkowa ku uczeniu CCCL rocznicy założenia i X wskrzeszenia Uniwersytetu Wileńskiego. T. II, Dziesięciolecie 1919-1929, Wilno 1929, s. 493. W sprawie tej zachowało się wystąpienie rektora do Ministerstwa Wyznań Religijnych i Oświecenia Publicznego z 15 VII 1922 r., zawierające następujące informacje: Rada Wydziału Lekarskiego na posiedzeniu 7 VII 1922 r. uchwaliła powołanie dr. Jasińskiego, „dotychczasowego starszego asystenta” kliniki pediatrycznej we Lwowie, na katedrę pediatrii w charakterze profesora nadzwyczajnego, i to z dniem 1 VII tego roku. Dwa dni później tę decyzję poparł Senat USB. Zob. LCVA F. 175, ap, I, B b nr 28, k. 3.

22 LCVA F.175, ap. 3, IX B nr 18/1, k. 78.

23 LCVA F. 175, ap. 1, I A nr 145, k. 99.

24 LCVA F. 175, ap. 1, I A nr 764, k. 18. 
remoncie urządzono oddział wewnętrzny ${ }^{25}$. Znajdowało się tam osiem sal po 7-8 tóżek, łącznie 60 miejsc ${ }^{26}$. Dwie sale przeznaczono na część obserwacyjną, gdzie przez dwa tygodnie przebywały wszystkie dzieci przyjmowane do kliniki. Pobyt dzieci w tym czasie służyć miał poznaniu etiologii chorób. Po tym okresie dzieci przenoszono do sal ogólnych. Dzieci z „otwartą gruźlicą" umieszczano w odrębnym pomieszczeniu. W dwóch innych salach ulokowani byli mali pacjenci w fazie obserwacji z początkowymi objawami zakażenia ${ }^{27}$. Od 1 listopada 1922 r. do 30 czerwca następnego roku przyjęto na leczenie 245 pacjentów. Zmarło w tym czasie 27 podopiecznych, z czego przeszło połowa z powodu gruźlicy ${ }^{28}$. Większość pacjentów z uwagi na brak postępów w leczeniu tej choroby przebywała w klinice aż do 50 dni. Należy też zaznaczyć, że gruźlica była wtedy najczęściej występującą jednostką chorobową na tym obszarze, chociaż nie jedyną. W tym czasie prócz gruźlicy (odnotowano 126 przypadków) diagnozowano dzieci z chorobami dróg oddechowych, narządów moczowych, przewodu pokarmowego. Nadto hospitalizowano dzieci chore zakaźnie, niejednokrotnie z rozpoznaniem grypy, odry, kokluszu, zapaleniem opon mózgowo-rdzeniowych, ale też osutkowego duru (plamistego) ${ }^{29}$. Przy szpitalu, w odrębnym skrzydle urządzono przychodnię pediatryczną. Przychodnia funkcjonowała pod nadzorem personelu kliniki. Pacjentów przyjmowano też w Poliklinice Chorób Dziecięcych, założonej przy ul Sawicz 10, gdzie prowadzono również zajęcia ze studentami ${ }^{30}$.W roku 1922-1923 zarejestrowano w Poliklinice 915 dzieci, udzielając 1869 porad $^{31}$.

Jak już jednak wspomniano, warunki pomieszczeń szpitalnych nie odpowiadały wymogom leczniczym, nie stanowiły też własności uniwersyteckiej. Nową siedzibą kliniki stać się miał I pawilon antokolskiego Szpitala Okręgowego WP, wcześniej przewidziany na mieszkania dla rodzin wojskowych. Kontynuowano jednak starania o bardziej dogodne dla kliniki i katedry pomieszczenia. Ostatecznie w lipcu 1923r., musiano jednak zaakceptować miejsce na kolejną - jak zaznaczano - tymczasową siedzibę, którą stał się I pawilon szpitala wojskowego. Pozyskane pomieszczenia przeznaczono na salę wykładową, przychodnię, gabinet światło-leczniczy. Ponadto zagospodarowano cztery sale, w których ulokowano 28 łóżeczek dla dzieci starszych, i dwie dla 10 niemowląt ${ }^{32}$. Prowadzono też praktykę lekarską i zajęcia ze studentami w śródmieściu, w już wspomnianej przychodni. Rozwinięto zakres funkcjonowania, tworząc stację opieki nad niemowlętami z poradnią dla matek oraz poradnię dla dzieci gruźliczych, utrzymywaną wspólnie z Wileńskim Towarzystwem Przeciwgruźliczym. Objęto też opieką oddział noworodków, rozmieszczony w dwóch odrębnych pomieszczeniach działu położniczego. Konsultowano noworodki leczone w wileńskim Szpitalu św. Jakóba ${ }^{33}$. W szkole położnych, znajdującej się w pobliżu tego szpitala, prowadzono ze studentami ćwiczenia z pielęgnacji noworodka, a praktyki - w żłobku, w placówce „Kropla Mleka”34. Nauczanie studentów w tym czasie, z uwagi na 
brak własnej, dostatecznie wszechstronnie zorganizowanej placówki, było jednak głównie teoretyczne. Starano się jednak podczas tych zajęć prezentować przypadki chorób dziecięcych. W pierwszym roku istnienia katedry w wykładach uczestniczyło 76 studentów, w następnym - 52. Przy czym z pediatrii, według obowiązujących przepisów, zajęcia miano prowadzić w ciągu dwóch trymestrów, w wymiarze łącznie 120 godzin. Faktycznie z uwagi na warunki kliniki i katedry była ona wykładana w dłuższym wymiarze czasu, aż do 180 godzin i w ciągu całego roku35. Ocena szefa katedry dotycząca sytuacji placówki była negatywna, przedstawiona została m.in. w sprawozdaniu z lutego 1924 r. $^{36}$ Dlatego też kontynuowano starania o inną lokalizację, tj. o przebudowę pawilonu II szpitala wojskowego. Spodziewano się tam uzyskać więcej pomieszczeń na zorganizowanie chociażby oddziału niemowlęcego i zakaźnego. Starano się też utrzymać dotychczasowe poradnie, rozmieszczone w śródmieściu ${ }^{37}$. Jednak terytorialne oddalenie placówek od kliniki spowodowało wkrótce (jeszcze w 1924 r.) ich likwidację, gdy stację opieki nad niemowlętami i poradnię dla dzieci kiłowych przeniesiono do przychodni klinicznej, a przychodnię przeciwgruźliczą - do poradni Wileńskiego Towarzystwa Przeciwgruźliczego ${ }^{38}$.

W marcu 1924 r. Jasiński zwołał pierwsze, organizacyjne zebranie Oddziału Polskiego Towarzystwa Pediatrycznego, gromadząc 20 pediatrów wileńskich, którzy odtąd odbywali pod jego przewodnictwem comiesięczne posiedzenia naukowe ${ }^{39}$.

Zrodził się też pomysł zorganizowania w uzdrowisku druskiennickim kolonii leczniczej dla dzieci i nadanie jej imienia Jędrzeja Śniadeckiego. Projekt zrealizowany został jeszcze w 1924 r. Wkrótce podczas dwóch turnusów przebywało w Druskiennikach 128 dzieci, kierowanych tam przez wileńskich lekarzy klinicznych ${ }^{40}$. Z ramienia kliniki w latach trzydziestych opiekę nad działalnością medyczną druskiennickiej kolonii sprawowała dr Hanna Kaulbersz-Marynowska ${ }^{41}$. Oceniała ona rezultaty leczenia uzdrowiskowego, prowadziła prace dotyczące wpływu kąpieli solankowych na skład frakcji białkowych, elektrolitów oraz odczynu opadania krwinek i tzw. efekt patergometryczny ${ }^{42}$. KaulberszMarynowska badała także wpływ diety jabłkowej na równowagę kwasowo-zasadową organizmu dziecka ${ }^{43}$.

Personel wileńskiej kliniki i katedry składał się wtedy z profesora, adiunkta, trzech starszych asystentów, dwóch młodszych oraz sióstr i posługaczek ${ }^{44}$. Z ówcześnie zatrudnionych Jasiński wymienił: lekarza naczelnego miejskiego (od lipca 1923 r.) szpitala dla dzieci -

35 Ibid

36 Ibid., k. 80.

37 LCVA F. 175, ap. 3, IX B nr 18/1, k. 80.

38 S. Trzebiński, op. cit., s. 445.

39 L. Łukowski, Przemówienia podczas uroczystego posiedzenia żałobnego w dniu 25 V 1936, [w:] Uroczyste posiedzenie żałobne poświęcone pamięci zmarłego w dniu $17 \mathrm{~V} 1936$ Profesora dra Wacława Jasińskiego, „Pamiętnik Wileński Towarzystwa Lekarskiego i Wydziału Lekarskiego USB” 1926, z. 3, s. 105.

40 S. Trzebiński, op. cit., s. 445.

41 Hanna Kaulbersz, po mężu Marynowska, była siostrą Jerzego Kaulbersza, krakowskiego profesora-fizjologa. Zmarła w 1962 r. w Warszawie. Zob. www.fizjologia.wl.cm.uj.edu.pl [dostęp 10.06.2020].

42 I. Sztachelska, J. Podgórski, Kaulbersz-Marynowska Hanna, [w:] Słownik biograficzny zasłużonych pediatrów, z. 2, red. E. Wilkoszewski, Warszawa 1990, s. 64; S. Hiller, Sprawozdanie z działalności Wydziału Lekarskiego USB w Wilnie w roku akademickim 1936/1937, „Pamiętnik Wileńskiego Towarzystwa Lekarskiego i Wydziału Lekarskiego Uniwersytetu Stefana Batorego" 1937, z. 4, s. 317.

43 H. Kaulbersz-Marynowska, Wpływ diety jabłkowej na równowagę kwasowo-zasadową, „Pediatria Polska” 1934, z. 5-6.

44 LCVA F. 175, ap. 3, IX B nr 18/1, k. 79. 
dr. M. Olenkiewicza, starszego asystenta - dr Jadwigę Niepokojczycką, młodszego asystenta - dr. Wacława Szuniewicza, oraz w pracującego przychodni dr. Adama Szwajkarta45.

Dla poprawy stanu opieki nad dzieckiem na terenie Wileńszczyzny Niepokojczycka organizowała kursy pielęgnacji dziecie ${ }^{46}$.

Dodać należy, że już od początku lat dwudziestych XX w. kształtowały się możliwości rozwoju sieci placówek leczniczych przeznaczanych do leczenia małych mieszkańców Wilna. Poprawiano warunki zapobiegania niebezpiecznym, szerzącym się wówczas choróbom zarówno zakaźnym, jak i społecznym. Organizowano placówki lecznicze przeznaczone do tych celów. Powstawały one zarówno pod patronatem uczelni, o czym już wspomniano, jak i samorządu, ale też z inicjatywy prywatnej czy związków wyznaniowych. W dawnej siedzibie kliniki pediatrycznej przy ul. Sióstr Miłosierdzia 12 nadal czynny był szpital dla dzieci. Na mocy ustawy o kasach chorych z 19 maja 1920 r. przy ul. Dominikańskiej 15 uruchomiono poradnię dla dzieci, gdzie kilka lat później przyjmowało czterech lekarzy chorób dziecięcych w tym prof. Jasiński oraz doktorzy Michał Lewin, Ludwik Łukowski i Witold Węsłowski ${ }^{47}$. W 1925 r. odnotowano w wykazach adresowych poradnię dla dzieci funkcjonującą przy Polskim Zrzeszeniu Lekarzy Specjalistów przy ul. Garbarskiej 3. Pracowali w niej dr Eugeniusz Iszora (zresztą pracownik katedry pediatrycznej) i dr A. Gettich ${ }^{48}$. W wykazach adresowych pod koniec lat dwudziestych wymieniono oddział neurologiczny Centralnej Przychodni dla Dzieci, czynny przy Zygmuntowskiej 4 m. $1^{49}$. Na Antokolu (Antokol 62) małych pacjentów przyjmowała dr Helena Biksiówna. W prawobrzeżnej, ubogiej dzielnicy Śnipiszki, przy ul. Kalwaryjskiej 29 praktykował dr Bolesław Żabko-Potapowicz ${ }^{50}$. Nadal funkcjonowała placówka „Kropli Mleka”, w latach dwudziestych już pod adresem Pohulanka 1. Dla dzieci zaś szkolnych czynna była poradnia przy ul. Wielkiej $3^{51}$ oraz oddział dentystyczny przy ul. Zakrętowej 9-552. Pojawiła się też funkcja lekarza szkolnego, notowana w wileńskich kalendarzach adresowych od końca lat dwudziestych ${ }^{53}$.

Tabela 2. Wyznaniowe instytucje lecznicze dla dzieci w Wilnie drugiej połowy lat dwudziestych XX w.

\begin{tabular}{|c|l|l|l|}
\hline Rok & \multicolumn{1}{|c|}{ Rodzaj } & \multicolumn{1}{|c|}{ Adres } & Prowadzący/status \\
\hline 1925 & $\begin{array}{l}\text { Pogotowie ratunkowe dla dzieci } \\
\text { chrześcijańskich }\end{array}$ & ul. Letnia 5 & brak danych \\
\hline 1925 & $\begin{array}{l}\text { Stacja opieki nad niemowlętami } \\
\text { „Oze” }\end{array}$ & ul. Mała Pohulanka 15 & dr A. Makowera \\
\hline 1928 & $\begin{array}{l}\text { Zakład leczniczy gminy żydowskiej } \\
\text { pediatryczno-ginekologiczny }\end{array}$ & ul. Witoldowa 15 & Prywatna \\
\hline
\end{tabular}

Źródło: Kalendarz wileński informacyjny na rok 1925, Wilno 1925, s. 140, 143; Kalendarz wileński, informacyjny 1927. Księga adresowa miasta Wilna, Wilno 1927, s. 116; Kalendarz wileński informacyjny 1928. Księga adresowa miasta Wilno, Wilno 1928, s. 99.

W. Jasiński, Sprawozdanie z Kliniki Chorób Dzieci, s. 327.

47 Kalendarz wileński informacyjny na rok 1925, Wilno 1925, s. II, 138, 139.

48 Ibid., s. 140.

49 Kalendarz wileński informacyjny na rok 1928, s. 99.

50 Ibid., s. 98.

51 Ibid.

52 Kalendarz wileński informacyjny 1928. Księga adresowa miasta Wilna, Wilno 1928, s. 99.

53 Ibid., s. 91-95. 
W 1926 r. uniwersytecką klinikę pediatryczną przeniesiono do przebudowanego rok wcześniej II pawilonu szpitala wojskowego, który umiejscowiony był w dolnym parku otaczającym antokolski szpital. Klinika składała się odtąd z 32 pomieszczeń, zajmując teren o powierzchni 1000 metrów kwadratowych ${ }^{54}$. W wyremontowanym obiekcie urządzono salę wykładową z amfiteatrem na 128 miejsc, pracownie, oddział ogólny z 48 łóżkami55, pokój obserwacyjny zaopatrzony w oszklone boksy, a ponadto odrębny oddział dla niemowląt o podobnej budowie z 12-16 łóżkami oraz kuchnię mleczną dla niemowląt i dzieci starszych. Dysponowano również gabinetem do leczenia światłem ${ }^{56}$. W nowych warunkach w klinice zwiększył się ruch chorych, i to o połowę, w porównaniu do początku lat dwudziestych. Zmniejszyła się natomiast liczba przyjmowanych dzieci z gruźlicą, co trudno wytłumaczyć tylko spadkiem odsetka zachorowań. Zmniejszyła się bowiem także liczba udzielonych porad zarażonym tą chorobą, co szczególnie zaobserwowano w roku akademickim 1927/1928. We wcześniejszych bowiem latach, od 1923/1924 do 1924/1925, zauważalny był tam wzrost przyjęć, nawet o połowę w stosunku do 1922/1923. Podobnie jednak było z przyjęciami do innych poradni znajdujących się pod opieką kliniki ${ }^{57}$. Stan ten można wytłumaczyć trwającą reorganizacją i przystosowywaniem obiektów do nowych zadań.

Zgodnie z planem odbywały się wykłady. Omawiano na nich właściwości anatomiczne i fizjologiczne organizmu dziecięcego, antropometrię kliniczną, naukę o żywieniu. Demonstrowano różne postaci chorób dziecięcych. Poznawano sposoby wykonywania różnych zabiegów, w tym szczepienia ospy, przeciwbłoniczego czy przeciwgruźliczego. Techniką szczepień oraz ich profilaktyczną skutecznością szczególnie interesował się Jasiński. W ramach ćwiczeń praktycznych uczono także studentów zasad racjonalnego odżywiania niemowląt. Cykl szkoleń z tego zakresu pod koniec lat trzydziestych prowadził dla studentów dr Eugeniusz Iszora ${ }^{58}$.

W miarę rozwoju przychodni, w tym też klinicznych, pojawiały się większe możliwości odbywania staży zawodowych w tych placówkach, np. w Stacji Opieki nad Matką i Dzieckiem czy w Stacji Przeciwkiłowej59. Powiększyła się też liczba pracowników katedry i kliniki. Oprócz poprzednio odnotowanych, których częściowo awansowano, zatrudniono nowych: w roku akademickim 1924/1925 dr. Eugeniusza Gerlée, od 1 października 1926 r. już jako adiunkta ${ }^{60}$. Korzystać można było także z różnych form doskonalenia zawodowego oraz zdobywania doświadczeń naukowych. Okazji do poszerzania wiedzy i prezentacji własnych dokonań dostarczały zjazdy międzynarodowe, jak np. Kongres Pediatryczny, który odbył się w 1930 r. w Sztokholmie, a siedem lat później w Rzymie. W ostatnim z wymienionych uczestniczyła Kaulbersz-Martynowska ${ }^{61}$. Starano się także podnosić poziom fachowy personelu pomocniczego, i to nie tylko zatrudnionego w wileńskich placówkach akademickich $^{62}$.

54 S. Trzebiński, op. cit., s. 445.

55 LCVA F. 175, ap. I, A b nr 156, k. 69.

56 Przy remoncie tej części szpitala starano się korzystać ze wzorów pediatrycznej kliniki wiedeńskiej, zob. ibid.

57 S. Trzebiński, op. cit., s. 446.

58 LCVA F. 175, ap. II, A b nr 925, k. 302.

59 S. Trzebiński, op. cit., s. 446.

60 LCVA F. 175, ap. I, A b nr 315, k. 258.

61 W. Jakowicki, Sprawozdanie Wydziału Lekarskiego za 1929/1930, „Pamiętnik Wileńskiego Towarzystwa Lekarskiego" 1930, z. 4-5, s. 388; LCVA F. 175, ap. 3, IX nr 13/80, k. 128.

62 LCVA F. 175, ap. I , A b nr 315, k. 258. 
Zwiększał się także, i to dość sukcesywnie, zasób inwentarza klinicznego i dydaktycznego ${ }^{63}$. Nabywano także książki i czasopisma. Jednak z powodu kryzysu zakupy sprzętowe czynione dla potrzeb placówki były minimalizowane. Redukowano je, podobnie jak w innych klinikach, do rzeczy najniezbędniejszych, często ograniczając do uzupełnienia bielizny szpitalnej ${ }^{64}$.

W roku akademickim 1931/1932 zdołano jednak ukończyć remont poczekalni w przychodni klinicznej. Umieszczono ją w oddzielnym budynku. Dwa lata później uruchomiono w budynku komendy szpitala wojskowego odrębny oddział izolacyjny, który składał się z trzech separatek i łazienki. Nie ulegała jednak poprawie sytuacja finansowa kliniki, a nawet następowało jej pogorszenie. Dnia 1 kwietnia 1932 r. magistrat miasta Wilna cofnął kredyty na utrzymanie Stacji Opieki nad Matką i Dzieckiem, funkcjonującej od ośmiu lat i służące najuboższym mieszkańcom dzielnicy antokolskiej. W tej sytuacji kierownictwo kliniki podjęło decyzję o samofinansowaniu działalności tej instytucji65. Pogłębiało się jednak zadłużenie kliniki. Trudności te wynikały z zaległości ubezpieczeniowych wobec kliniki, głównie z długów instytucji państwowych ${ }^{66}$.

Pewna jednak zmiana warunków leczenia osiągnięta została przez determinację kierownika i personelu. Miała ona wpływ na stabilizację funkcjonowania kliniki. Decydowała o rozwoju kadry i stopniowym wzroście liczby publikacji. Pracownicy naukowi ogłaszali je co prawda już od początku funkcjonowania katedry, lecz od 1926 r. ze znacznie większą częstotliwością. Artykuły drukowane były przeważnie w „Pediatrii Polskiej”, „Polskiej Gazecie Lekarskiej”, „Medycynie” oraz „Pamiętniku Wileńskiego Towarzystwa Lekarskiego", zatem głównie w czasopismach polskich. Wśród prac przeważały jednak kazuistyczne, o charakterze przyczynkarskim. Omawiano przypadki wścieklizny, rzeżączkowego zapalenia stawu łokciowego, zapaleń opon mózgowo-rdzeniowych, odczynu Biernackiego u niemowląt z kiłą wrodzoną, rozpatrywano znaczenie ergosteryny w patogenezie i leczeniu krzywicy. Ponadto badano zjawisko skurczu i zwężenia odźwiernika u niemowląt ${ }^{67}$. Ogłaszano też sprawozdania z działalności kolonii leczniczych w Druskiennikach i wileńskiej Stacji Opieki nad Matką i Dzieckiem ${ }^{68}$. W roku akademickim 1932/1933 wydrukowano 17 publikacji69. Jasiński pracował nad podręcznikiem pediatrii, którego brak odczuwano w dydaktyce. Podręcznik ukazał się jednak dopiero po śmierci profesora ${ }^{70}$.

63 S. Trzebiński, op. cit., s. 447

64 LCVA F. 175, ap. I, A b, nr 315, k. 258.

65 W. Jasiński, Sprawozdanie z działalności Wydziału Lekarskiego USB za 1931/1932, „Pamiętnik Wileńskiego Towarzystwa Lekarskiego" 1932, z. 4-5, s. 303.

66 Dodać można, że kłopoty finansowe, głównie zadłużenie Urzędu Wojewódzkiego wobec klinik, dotyczyło także innych jednostek, w tym kliniki wewnętrznej. Zob. LCVA F. 175, ap. I, A b nr 872, k. 128 (Pismo do Ministerstwa Wyznań Religijnych i Oświecenia Publicznego z 21 I 1937 r. z wykazem zadłużenia, podpisane przez prorektora prof. Józefa Patkowskiego).

67 E. Gerlèe, Skurcz i zwężenie odźwiernika u niemowląt na podstawie materjału Kliniki Dziecięcej USB w Wilnie, „Pediatria Polska” t. 14, 1934, nr 5-6, s. 251-258.

68 LCVA F. 175, ap I, A b nr 315, k. 258.

69 LCVA F. 175, ap. I, A b nr 313, k. 135

70 M.M. Kamińska, Jasiński Wacław, s. 63. 
Podczas choroby profesora i po jego śmierci (17 maja 1936 r) działalnością kliniki i katedry zajmowała się Kaulbersz-Marynowska71. Jak wynika z protokołu Rady Wydziału z dnia 26 maja 1926 r. powierzono jej tymczasowe kierownictwo kliniki, podobnie jak uprzednio wspomniany nadzór nad kolonią letnią w Druskiennikach ${ }^{72}$. Warto dodać, że KaulberszMarynowska była brana pod uwagę przy ustalaniu listy kandydatur do obsadzenia - na stałe - stanowiska kierownika katedry i kliniki pediatrycznej w USB. Listę kandydatur na mocy uchwały Rady Wydziału z dnia 25 czerwca 1926 r. rozpatrywała specjalnie powołana komisja. Początkowo dopuszczono do udziału w konkursie sześciu kandydatów, przedstawicieli wszystkich ośrodków uniwersyteckich z kraju. Była to zresztą praktyka dość powszechnie stosowana w okresie międzywojennym. W listopadzie tego roku ustalono ostateczną listę preferowanych osób do tej funkcji, wśród których, prócz wyżej wymienionej znajdowali się pediatrzy: doc. dr Henryk Brokman i doc. dr Stanisław Torokan-Popowski z Warszawy oraz dr Władysław Bujak z Krakowa. Dla wybrania ostatecznej kandydatury przeprowadzono aż pięć posiedzeń komisji. Na ostatnim, które odbyło się 7 stycznia 1937 r., po dyskusji wskazano jednogłośnie Bujaka ${ }^{73}$. Z powodu braku dokumentów trudno stwierdzić, dlaczego nie powołano na stanowisko Kaulbersz-Marynowskiej. Uznano być może, że byłby to precedens na Wydziale Lekarskim USB. Środowisko lekarskie nie było zapewne jeszcze gotowe do powierzenia tak ważnej funkcji kobiecie, pomimo doceniania jej zasług naukowych i sukcesów na polu wileńskiej pediatrii ${ }^{74}$.

14 stycznia 1937 r. Rada Wydziału ostatecznie powierzyła kierownictwo katedry i kliniki dr Władysławowi Bujakowi z Uniwersytetu Jagiellońskiego ${ }^{75}$. Bujak, podobnie jak wcześnie Jasiński uzyskał tytuł profesora nadzwyczajnego pediatrii ${ }^{76}$.

Bujak podkreślał w swych badaniach odrębność reakcji ustroju dziecka na różne czynniki zewnętrzne i wewnętrzne. Interesował się zmianami w nerkach, zjawiskiem ropomoczu. Ponadto zajmował się zapaleniem opon mózgowo-rdzeniowych ${ }^{77}$. Do momentu objęcia katedry i kliniki przez Bujaka wykłady dla IV roku przez trzy semestry prowadziła Kaulbersz-Marynowska.

Ćwiczenia dotyczące sposobów badania dziecka realizowali pozostali pracownicy naukowi. Iszora kontynuował zajęcia z zasad odżywiania ${ }^{78}$. Zajęcia te pomogły mu zapewne w przygotowaniu Praktycznego podręcznika odżywiania dzieci, wydanego w 1931 r. nakładem Rocznych Kursów Pielęgnowania i Wychowania Dzieci, a także dalszych prac z tego cyklu: Odżywiania niemowląt w 1935 r., a dwa lata później Odżywiania dzieci w wieku przedszkolnym i szkolnym ${ }^{79}$.

71 I. Sztachelska, J. Podgórski, Kulbersz-Martynowska Hanna, s.64.

72 LCVA F. 175, ap. 3, IX B nr 80, k. 123; Skład Uniwersytetu w roku akademickim 1936/37, Wilno 1937, S. 41

73 LCVA F. 175, ap. I ,B b nr 705, s. 40-41, 45-47, 49-50.

74 Por. B. Urbanek, Kariery naukowe kobiet na Wydziale Lekarskim USB w Wilnie w okresie międzywojennym (1919-1939), "Medycyna Nowożytna. Studia nad Kulturą Medyczną” t. 24, 2018, z. 1, s. 86-91.

75 Władysław Bujak (1883-1969). M. Hanicka, Bujak Władysław, [w:] Słownik biograficzny zasłużonych pediatrów, z. 2, s.18; LCVA F.175, ap.I ,B b nr 28, k. 4.

76 LCVA F. 175, ap. l, A b nr 925, k. 147-148.

77 M. Hanicka, Bujak Władysław, s. 18.

78 LCVA F. 175. ap. I, A b nr 925, k. 303.

79 M. Kamińska, Iszora Eugeniusz, [w:] Słownik biograficzny zasłużonych pediatrów, z. 2, s. 47. 
Ćwiczenia ze studentami prowadzono też w miejskim szpitalu zakaźnym. W roku akademickim 1937/1938 kontynuowali obowiązki akademickie: asystent starszy doc. dr Hanna Kaulbersz-Marynowska, asystent starszy dr Pesia Lidzka, asystent łącznikowy kpt. dr Konstantyn Korolkiewicz, (p.o.) asystent młodszy lekarz Maria Mikołajkiewiczówna, (p.o.) asystent młodszy lekarz Marian Chmielewski, (p.o.) asystent dr Władysława Kiejlotisówna, (p.o.) asystent młodszy lekarz Maria Tarasiewiczówna. Ponadto pracowało pięć pielęgniarek, cztery sanitariuszki, jeden sanitariusz, dwie pomoce i jeden woźny ${ }^{80}$.

W tym czasie Bujak prowadził wykłady dla studentów IV roku w wymiarze czterech godzin. Tyleż samo godzin dla studentów tego roku w formie ćwiczeń przydzielono pozostałym pracownikom. Dodatkowo Kaulbersz-Marynowska realizowała wykład z zakresu anatomii i fizjologii dziecka, a w ostatnim semestrze $V$ roku diagnostykę chorób dziecięcych. Zajęcia te prawdopodobnie utrzymane zostały do końca funkcjonowania katedry i kliniki oraz do likwidacji USB, tj. do połowy grudnia $1939 \mathrm{r}^{81}$

\section{Próba podsumowania}

Na przestrzeni lat 1922-1939 wkład pracowników wileńskiej kliniki w rozwój pediatrii - nowej dziedziny lekarskiej na tym terenie, jak ją określił Jasiński - był poważny. W tym procesie ważną rolę odegrała jej kadra kierownicza, co widać chociażby w funkcjonowaniu wileńskiej kliniki i katedry oraz w tworzeniu dorobku naukowego. Koncentrowano się w dużym stopniu na analizie zasadności stosowania szczepień ochronnych, w tym przeciwgruźliczych, przeciwbłoniczych, na przesłankach do aplikowania dzieciom, na profilaktyce odry surowicy ozdrowieńców. Ponadto prowadzono prace badawcze z dietetyki dziecięcej i poznawaniu efektów leczenia uzdrowiskowego. Za sprawą Jasińskiego wydano także podręcznik o chorobach dzieci. Następnie, w drugiej połowie lat trzydziestych, za czasów kierownictwa Bujaka, powiększano dorobek publikacyjny ${ }^{82}$. Istotna była także rola dydaktyczna pracowników katedry w kształtowaniu środowiska specjalistów na tym terenie, a także, na co też warto zwrócić uwagę, w powstawaniu w latach trzydziestych nowych placówek dziecięcych o szerszym, także społecznym profilu. Jednym z przykładów może być udział pediatrów w tworzeniu żłobków opartych na nowszych osiągnięciach pedagogiki społecznej i wiedzy z zakresu profilaktyki medycznej. Do jednej z wzorcowych instytucji, przeznaczonej dla dzieci opuszczonych, tzw. podrzutków należał żłobek-ochronka nazwana imieniem „Marii”, gdzie m.in. badano sposoby i efektywność odżywiania niemowląt według metody Pirqueta. Do 1936 r. zwiększono też liczbę miejskich stacji opieki nad matką i dzieckiem z 2 do 12 placówek $^{83}$. Instytucje te były ważne w rozwijaniu prozdrowotnej świadomości społeczeństwa.

Od 1919 r. następował wzrost, wprawdzie powolny, liczby lekarzy opiekujących się dziećmi, mimo występujących w poszczególnych latach pewnych wahań. Oczywiście nie mógł on zaspakajać wszystkich potrzeb w zakresie opieki nad dzieckiem, zwłaszcza

82 B. Kempińska-Mirosławska, op. cit., s. 397, 400, 405,

83 L. Łukowski, op. cit., s. 105. 
mieszkańców województwa ${ }^{84}$. Wskazuje na ten fakt liczba 27 specjalistów w 1939 r. Stan ten stanowić mógł początek dalszego rozwoju pediatrii na Wileńszczyźnie, przerwanego w 1939 r.

\section{Bibliografia}

\section{Źródła archiwalne}

Lietuvos centrinis valstybės archyvas w Wilnie [LCVA]:

- Dokumenty dotyczące magistratu $\mathrm{m}$. Wilna:

64/19/3; 64/24/38; 64/24/65.

- Dokumenty dotyczące USB:

F. 175, ap. I, B b nr 28; F. 175, ap. 3, IX B nr 18/1; F. 175, ap. 1, I A nr 145; F 175, ap. I, A b, nr 161; F. 175, ap. I , A b nr 315; F. 175, ap. 1, I A nr 764; F. 175, ap. 30, IX B nr 80; F. 175, ap. I, B b nr 28; F. 175 ap. I, B b nr 705; F. 175, ap. I, A b nr 925.

\section{Źródła drukowane}

XXI Spis wykładów na trzy trymestry, Wilno 1939.

„Dziennik Wileński” t. 2, 1917, nr 217, z 22 września 1917 r.

Kłos J., Wilno, Przewodnik krajoznawczy, Wilno 1937.

Kalendarz ilustrowany „Kurjera Litewskiego" na rok 1909, Wilno 1909.

Kalendarz wileński, informacyjny 1927. Księga adresowa miasta Wilna, Wilno 1927.

Kalendarz wileński informacyjny 1928. Księga adresowa miasta Wilno, Wilno 1928.

Kalendarzy informacyjny 1929. Księga adresowa miasta Wilno, Wilno 1929.

Księga adresowa m. Wilna. Wileński Kalendarz informacyjny na rok 1933, Wilno 1933.

Księga adresowa m. Wilna 1935. Wileński Kalendarz informacyjny, Wilno 1935.

„Pamiętnik Wileński Towarzystwa Lekarskiego i Wydziału Lekarskiego Uniwersytetu Stefana Batorego" 1930, z. 4-5; 1936, z. 3; 1937, z. 4.

„Pedjatrja Polska” 1923, nr 5; 1934, z. 5-6.

Rocznik Uniwersytetu Stefana Batorego w Wilnie 1937-1938, Wilno 1938.

Skład Uniwersytetu w roku akademickim 1936/37, Wilno 1937.

Trzebiński S., Wydział Lekarski Uniwersytetu Stefana Batorego w latach 1919-1929, [w:] Księga pamiątkowa ku uczeniu CCCL rocznicy założenia i X wskrzeszenia Uniwersytetu Wileńskiego. T. II, Dziesięciolecie 1919-1929, Wilno 1929.

Wilno i woj. Wileńskie. Informator społeczno-gospodarczy i księga adresowa m. Wilna i woj. Wileńskiego, Wilno 1937.

Wilno i województwo wileńskie. Informator i Księga adresowa na rok 1939, Wilno 1939.

\section{Literatura przedmiotu}

Kempińska-Mirosławska B., Pediatria, [w:] Dzieje medycyny w Polsce. T. 2, lata 1914-1944, red. W. Noszczyk, J. Supady, Warszawa 2015.

Słownik biograficzny zasłużonych pediatrów, z. 1, red. E. Wilkoszewski, Warszawa 1985.

84 Przychodnie specjalistyczne znajdowały się bowiem w większych miastach, zob. B. Urbanek Lekarze kresowi a dylematy praktyki medycznej, s. 43. 
Słownik biograficzny zasłużonych pediatrów, z. 2, red. E. Wilkoszewski, Warszawa 1990. Urbanek B., Kształtowanie się specjalności lekarskich na ziemiach polskich w latach 18601914, Warszawa 2010.

Urbanek B., Lekarze kresowi a dylematy praktyki medycznej w drugiej połowie lat 20. do 1933 r., (tzw. ustawy scaleniowej), [w:] Medycy polskiego pogranicza II Rzeczypospolitej 1918-1939, red. B. Urbanek, Warszawa 2018.

\section{Strony internetowe}

www.fizjologia.wl.cm.uj.edu.pl [dostęp 10.06.2020].

Bożena Urbanek jest profesorem w Instytucie Historii Nauki im. L. i A. Birkenmajerów PAN. Interesuje się historią medycyny zarówno w zakresie organizacji, jak i koncepcji teoretycznych tej dyscypliny nauki, obowiązujących w XIX i XX w.

e-mail: bozenaurbanek@wp.pl

Data zgłoszenia artykułu: 21 lutego 2020

Data przyjęcia do druku: 7 lipca 2020 